\title{
Jatkuvatoiminen veden laadun seuranta hajakuormituksen arvioinnissa
}

\author{
Pasi Valkama, Kirsti Lahti ja Asko Särkelä \\ Vantaanjoen ja Helsingin seudun vesiensuojeluyhdistys ry \\ Asemapäällikönkatu 12 C, 00520 Helsinki, \\ etunimi.sukunimi@vesiensuojelu.fi
}

Maataloudesta tuleva hajakuormitus vaihtelee voimakkaasti hydrologisten olosuhteiden mukaan. Tällöin näytteenoton tiheydellä ja ajoittumisella on hyvin suuri merkitys kiintoaine- ja ravinnekuormien arvioinnissa. Yksittäisillä virtaamapainotteisillakin vesinäytteillä veden laadussa tapahtuvat nopeat vaihtelut jäävät usein havaitsematta ja siten niiden perusteella tehtävät kuormituslaskelmat usein antavat väärän kuvan kokonaiskuormituksesta. Automaattisilla, jatkuvatoimisilla mittausantureilla nopeatkin veden laadussa tapahtuvat muutokset tulevat esiin ja niihin perustuvat kuormituslaskelmat antavat ravinnekuormasta tarkemman kuvan.

Tässä tutkimuksessa vertailtiin pienestä pelto-ojasta ja suuremmasta Lepsämänjoesta eri laskentamenetelmillä saatuja kokonaisfosforikuormia. Kokonaisfosforikuormat laskettiin yksittäisiin vesinäytteisiin perustuen ja mittausantureilla saadun mittaustiedon perusteella. Antureiden tunnin välein tuottaman sameus- ja vedenkorkeustiedon perusteella voitiin laskea erittäin tarkasti uomassa tutkimusaikana kulkeutunut kokonaisfosforikuorma. Tiheän mittausvälin ansiosta nopeatkaan veden laadussa tapahtuvat muutokset sekä todelliset minimi- ja maksimiarvot eivät jääneet havaitsematta. Perinteisesti valuma-alueilta tulevaa kuormitusta on laskettu yksittäisiin vesinäytteistä määritettyihin pitoisuuksiin ja vuorokauden keskivirtaamatietoihin perustuen. Joissain tapauksissa kuormituslaskennat perustuvat pidempiaikaisiin keskiarvopitoisuuksiin ja keskivirtaamiin.

Tutkimuksessa havaittiin pienen pelto-ojan ja Lepsämänjoen kevät- ja syystulvan aikaisten kokonaisfosforipitoisuuksien vaihtelevan hyvin voimakkaasti ja nopeasti muutaman tunnin sisällä. Kokonaisfosforikuormat vaihtelivat myös voimakkaasti eri tutkimusjaksojen välillä riippuen hydrologisista olosuhteista. Hajakuormituslaskelmat ja maataloudesta tulevan kuormituksen arviot perustuvat yleensä juuri pieniltä valuma-alueilta yksittäisten vesinäytteiden perusteella tehtyihin kuormituslaskelmiin. Tähän menetelmään perustuvien kuormituslaskelmien lopputuloksissa yhdellä yksittäisellä korkealla pitoisuudella voi olla lopputuloksen kannalta hyvin suuri merkitys. Näytteenottoajankohdalla ja -tiheydellä on suuri merkitys laskentajakson kuormituslaskentojen lopputuloksiin. Tutkimuksen perusteella näyttää siltä, että perinteisin menetelmin tehdyt, yksittäisiin vesinäytteisiin perustuvat kuormituslaskelmat saattavat antaa hyvin virheellisen kuvan ravinnekuormista. Jos näytteenotto ajoittuu tulva-ajan korkeiden pitoisuuksien ajalle, voivat vesinäytteisiin perustuvat fosforikuormalaskelmat antaa jopa useita kertoja suuremman tuloksen.

Asiasanat: hajakuormitus, automaattinen veden laadun seuranta, kokonaisfosforikuorma, Lepsämänjo$\mathrm{ki}$ 


\section{Johdanto}

Suomessa on seurattu säännöllisesti vesistöjen veden laatua jo 1960-luvulta alkaen (Niemi 2006). Seurannan tarkoituksena on tuottaa tietoa veden laadun ajallisista ja paikallisista muutoksista. Tiheimmillään vesinäytteitä on otettu kerran kuukaudessa, mutta yleisimmin vain muutaman kerran vuodessa. Virtavesien luonteeseen kuuluvat nopeat veden määrän ja laadun muutokset (Hynes 1970; Niemi 1998). Tämä aiheuttaa näytteenotolle suuria haasteita.

Vantaanjoen ja Helsingin seudun vesiensuojeluyhdistyksessä aloitettiin vuoden 2005 syksyllä automaattisten veden laatua seuraavien mittausantureiden koekäyttö savisameissa Vantaanjoen valuma-alueen virtavesissä (Särkelä ym. 2006). Anturitutkimuksen tulokset olivat lupaavia ja ensimmäistä kertaa saatiin hyviä arvioita hajakuormasta mittausantureiden tulosten perusteella.

Maatalouden aiheuttamaa hajakuormitusta on tutkittu paljon ja sen suuruutta on selvitetty tutkimalla virtavesien ravinnekuljetusta (Nykänen 1991; Leinonen 1992; Lehtinen ym. 1993; Räike ym. 2004), mutta myös mallintamalla (mm. Kauppi 1982; Scherer 2000). Hajakuormituksen ajoittumisen ja suuruuden todentaminen on hankalaa, etenkin perinteisin näytteenottomenetelmin. Hajakuormituksen ajallisen vaihtelun ja suuruuden entistä tarkempi selvittäminen antaa mahdollisuuden pohtia keinoja, joilla kuormitusta saataisiin tehokkaasti vähennettyä. Jatkuvatoimisella veden laadun seurannalla on mahdollista saada esiin veden laadun muutokset, joita normaalilla tarkkailulla ei havaita. Automaattisten vedenlaatuasemien toimintavarmuuden ja tarkkuuden parantuminen on tehnyt niistä lupaavan vaihtoehdon veden laadun nopeiden muutosten havainnointiin (Valkama ym 2007b).

Tutkimuskohteena ollut pelto-ojan valuma-alue sijaitsee Nurmijärven kunnassa Lepsämänjoen latvoilla. Pinta-alaltaan se on $2,6 \mathrm{~km}^{2}$, josta peltoa on 39 prosenttia. Lähes kaikki peltoalue sijoittuu valuma-alueen alaosaan ja pellot ovat hyvin tasaisia savipeltoja. Lepsämänjoen yläosan valuma-alue on noin kymmenen kertaa suurempi ja sen peltoprosentti on 36,5 prosenttia. Valuma-alueen pellot sijoittuvat jokiuoman varrelle savisille alueille.

Tässä tutkimuksessa oli tavoitteena selvittää erilaisten hydrologisten olosuhteiden aikana erilaisilla laskentamenetelmillä saatuja kokonaisfosforin kuormitusmääriä erikokoisilta peltovaltaisilta valuma-alueilta sekä mahdollisia tulosten erilaisuuteen johtavia syitä ja seurauksia. Tutkimuskohteena olleen pelto-ojan veden laatua on seurattu neljän eri tutkimusjakson aikana: syksyllä 2005, keväällä 2006, syksyllä 2006 ja keväällä 2007. Vertailukohtana laskettiin noin kymmenen kertaa suuremman Lepsämänjoen yläosan valuma-alueen kokonaisfosforikuormat samoilta ajankohdilta. Pelto-ojan ja Lepsämänjoen kokonaisfosforikuormia ja laskentamenetelmiä on esitelty myös aikaisemmin Särkelä ym. (2006), Valkama ym. (2007a) ja Valkama ym. (2007b) toimesta.

\section{Aineisto ja menetelmät}

Automaattinen YSI:n valmistama mittausanturi kiinnitettiin Lepsämänjoen yli kulkevan puusillan rakenteisiin vertikaalisesti lähelle pohjaa. Anturista erilleen siltarakenteisiin kiinnitettiin jatkuvatoimisesti vedenkorkeutta mittaava paineanturi. Pelto-ojassa YSI:n anturi kiinnitettiin vaaka-asentoon betonilaattaan kiinnitettyihin teräskiinnikkeisiin. Betonilaatta laskettiin ojan pohjalle, jolloin anturi tuli vaakatasoon noin 20 senttiä uoman pohjan yläpuolelle. Mittaustaajuudeksi valittiin yksi tunti. Anturin mahdolliset mittausparametrit olivat veden lämpötila, sähkönjohtavuus ja sameus. Mittausantureiden tuottama tieto tallennettiin Luode-dataloggerille ja siirrettiin GSM-tekniikkaa hyödyntävän lähetinyksikön kautta antureista vastanneen palveluntarjoajan palvelimelle, jonne tulokset päivittyivät kaksi kertaa vuorokaudessa.

Mittauspisteiltä otettiin vesinäytteitä Limnos-noutimella anturin mittaussyvyydestä erilaisten virtaamaolojen aikana anturin tuottaman mittaustiedon ja laboratoriossa tehtävien analyysien tulosten vertailuun. Laboratoriossa vesinäytteistä analysoitiin säännöllisesti sameus, kiintoainepitoisuus 0,4 mikrometrin kalvosuodattimilla (Npc), sähkönjohtavuus, kemiallinen hapenkulutus $\left(\mathrm{COD}_{\mathrm{Mn}}\right)$, kokonaistyppi, nitriitti- ja nitraattitypen pitoisuus, kokonaisfosfori ja liuennut fosfaattifosfori. Osasta näytteitä määritettiin myös happipitoisuus ja hapen kyllästysaste, $\mathrm{pH}$, väriluku ja ammoniumtyppi. Analyysejä tehtiin Helsingin kaupungin ympäristökeskuksen laboratoriossa ja Suomen ympäristökeskuksen laboratoriossa. Kevään 2007 pelto-ojan laboratorioanalyysit tehtiin Suunnittelukeskuksen laboratoriossa Helsingissä. Analyysimenetelmät olivat pääasiassa SFS-EN/ISO-standardimenetelmiä.

Virtaama tutkimuspisteessä selvitettiin siivikoimalla laaditun purkautumiskäyrän perusteella. Purkautumiskäyrän ja paineanturin mittaaman vedenkorkeustiedon avulla uomien virtaamat voitiin 
laskea tunnin välein. Virtaaman kannalta olennainen valuma-alueen sademäärätieto saatiin Ilmatieteen laitoksen Nurmijärven Röykän sääasemalta.

Anturin mittaaman sameuden ja laboratoriossa määritetyn veden kokonaisfosforipitoisuuden välillä todettiin erittäin merkitsevä positiivinen korrelaatio (kuva 1) pelto-ojassa $(r=0,99, n=25)$ ja Lepsämänjoessa $(r=0,96, n=37)$. Näin sameuden perusteella voitiin laskea kokonaisfosforipitoisuus tunnin välein (Valkama ym. 2007b).

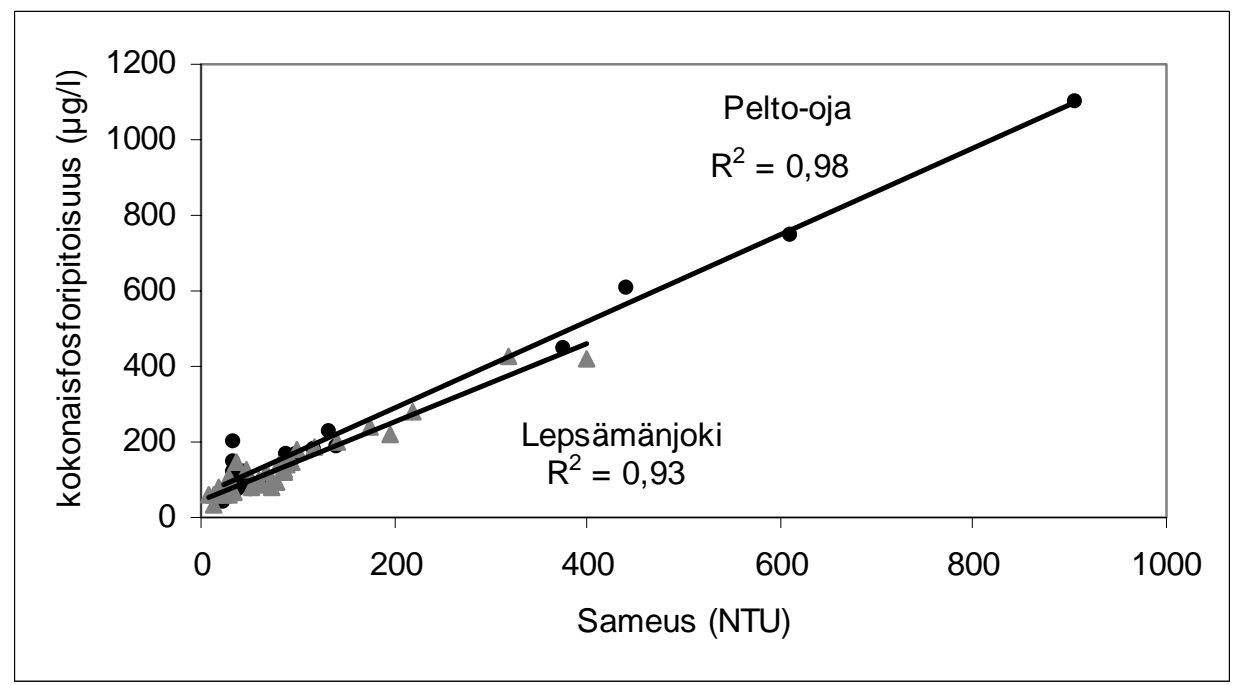

Kuva 1. Sameuden ja kokonaisfosforipitoisuuden välillä todettiin erittäin merkitsevä korrelaatio niin pelto-ojan kuin Lepsämänjoenkin tuloksissa.

Perinteisesti tietyn ajanjakson kokonaisfosforikuorma on laskettu yksittäisistä vesinäytteistä määritettyjen kokonaisfosforipitoisuuksien avulla. Tässäkin tutkimuksessa jakson aikana kulkeutuva fosforin määrä laskettiin myös kertomalla näytteenottohetken kokonaisfosforipitoisuus laskentajakson keskivirtaaman perusteella lasketun jakson aikana virranneen veden määrällä. Laskentajaksot katkaistiin siitä kohdasta, missä virtaama oli lähempänä seuraavan näytteenottohetken virtaamaa. Näin haluttiin parantaa laskentajakson näytteen edustavuutta.

\section{Tulokset ja tulosten tarkastelu}

Taulukkoon 1 on kerätty pelto-ojan ja Lepsämänjoen neljän tutkimusjakson aikaiset kokonaisfosforikuormat. Ojassa ja joessa kulkeutuvat kuormat on laskettu anturien mittaaman tiedon perusteella sekä yksittäisiin vesinäytteisiin perustuen edellä kuvatulla menetelmällä.

Taulukko 1. Tutkimusjaksojen aikaiset kokonaisfosforikuormat pelto-ojassa ja Lepsämänjoessa eri menetelmillä laskettuna, jaksojen keskivirtaamat, sademäärät ja jaksojen pituudet. Keväällä 2006 ojan tutkimusjakso oli pidempi kuin Lepsämänjoen.

\begin{tabular}{|c|c|c|c|c|c|c|c|c|}
\hline \multirow[t]{2}{*}{$\begin{array}{l}\text { Tutkimus- } \\
\text { jakso }\end{array}$} & \multicolumn{2}{|c|}{$\begin{array}{l}\text { kokonaisfosforikuorma } \\
\text { kg/tutkimusjakso } \\
\text { anturidatan perusteella }\end{array}$} & \multicolumn{2}{|c|}{$\begin{array}{l}\text { kokonaisfosforikuorma } \\
\text { kg/tutkimusjakso } \\
\text { näytteiden perust. } \\
\end{array}$} & \multicolumn{2}{|c|}{$\begin{array}{c}\text { jakson } \\
\text { keskivirtaama } \\
\text { I/s }\end{array}$} & $\begin{array}{c}\text { jakson } \\
\text { sademäärä } \\
\text { mm }\end{array}$ & $\begin{array}{l}\text { jakson } \\
\text { pituus } \\
\text { d }\end{array}$ \\
\hline & oja & joki & oja & joki & oja & joki & & \\
\hline syksy 2005 & 0,5 & 16 & 0,5 & 16 & 2 & 60 & 34 & 29 \\
\hline kevät 2006 & 55 & 182 & 110 & 138 & 70 & 500 & 27 & $35 / 22$ \\
\hline syksy 2006 & 9 & 78 & 19 & 199 & 20 & 240 & 194 & 29 \\
\hline kevät 2007 & 21 & 250 & 26 & 225 & 30 & 340 & 66 & 51 \\
\hline
\end{tabular}

Kevättulvan aikaiset fosforikuormat olivat syystulvan aikaisia suurempia molemmissa uomissa. Keskivirtaama korreloi positiivisesti fosforikuorman kanssa, mutta tutkimusjakson sademäärän kasvu ei välttämättä johtanut kuormituksen kasvuun. Merkittävä tekijä oli keväällä sulaneen lumen määrä ja sulamisnopeus. Keväällä 2006 Lepsämänjoen mittausjakso oli huomattavasti lyhyempi kuin pelto-ojan vastaava.

Kokonaisfosforipitoisuudet vaihtelivat eri tutkimusjaksoilla hyvin voimakkaasti hydrologisten tekijöiden mukaan. Syksyn 2005 eri menetelmillä määritetyt kokonaisfosforikuormat ovat hyvin yhte- 
neviä johtuen pitoisuuksien pienestä vaihtelusta tutkimusjaksolla. Tämän tutkimusjakson aikana satoi $34 \mathrm{~mm}$ ja ojan ja joen virtaamat tutkimusjaksolla olivat hyvin pieniä. Tutkimusjakson lopun sateet nostivat virtaamaa ja kiintoainepitoisuutta sekä kokonaisfosforipitoisuutta. Kiintoaine- ja kokonaisfosforipitoisuudet vaihtelivat kaikilla tutkimusjaksoilla hyvin yhtenevästi. Tämä johtuu fosforin voimakkaasta sitoutumisesta savihiukkasten alumiini- ja rautaoksidipolymeereihin (Aura ym. 2006). Pitoisuudet vaihtelivat pientenkin virtaamassa tapahtuvien muutosten yhteydessä. Suurempi muutos virtaamassa nosti pitoisuuden hetkellisesti hyvin korkeaksi. Virtaamahuippua edeltävä kokonaisfosforipiikki johtui virtaaman nousuvaiheessa uoman pohjalle kasaantuneen kiintoaineksen äkillisestä liikkeelle lähdöstä (kuva 2). Saman ovat todenneet myös Tikkanen ym. (1985).

Keväällä 2006 saatiin pelto-ojasta yksittäisiin näytteisiin perustuvalla menetelmällä kaksi kertaa suurempi fosforikuorma kuin anturitulosten perusteella. Tällöin pitoisuusvaihtelut olivat nopeita ja hyvin huomattavia ja yhdellä huippuvirtaaman aikaisella korkealla pitoisuudella oli lopputulokseen erittäin suuri merkitys. Lepsämänjoesta otetut näytteet eivät sen sijaan edustaneet huippupitoisuuksia, vaan kaikki näytteet otettiin tulvajakson jälkeen. Tästä syystä anturin mittaamien tulosten perusteella saatiin suurempi kokonaisfosforikuorma kuin yksittäisiin näytteisiin perustuen. Mitä voimakkaampi kokonaisfosforipitoisuuden vuorokausivaihtelu on tulva-aikana, sitä suurempi merkitys on näytteenottohetkellä.
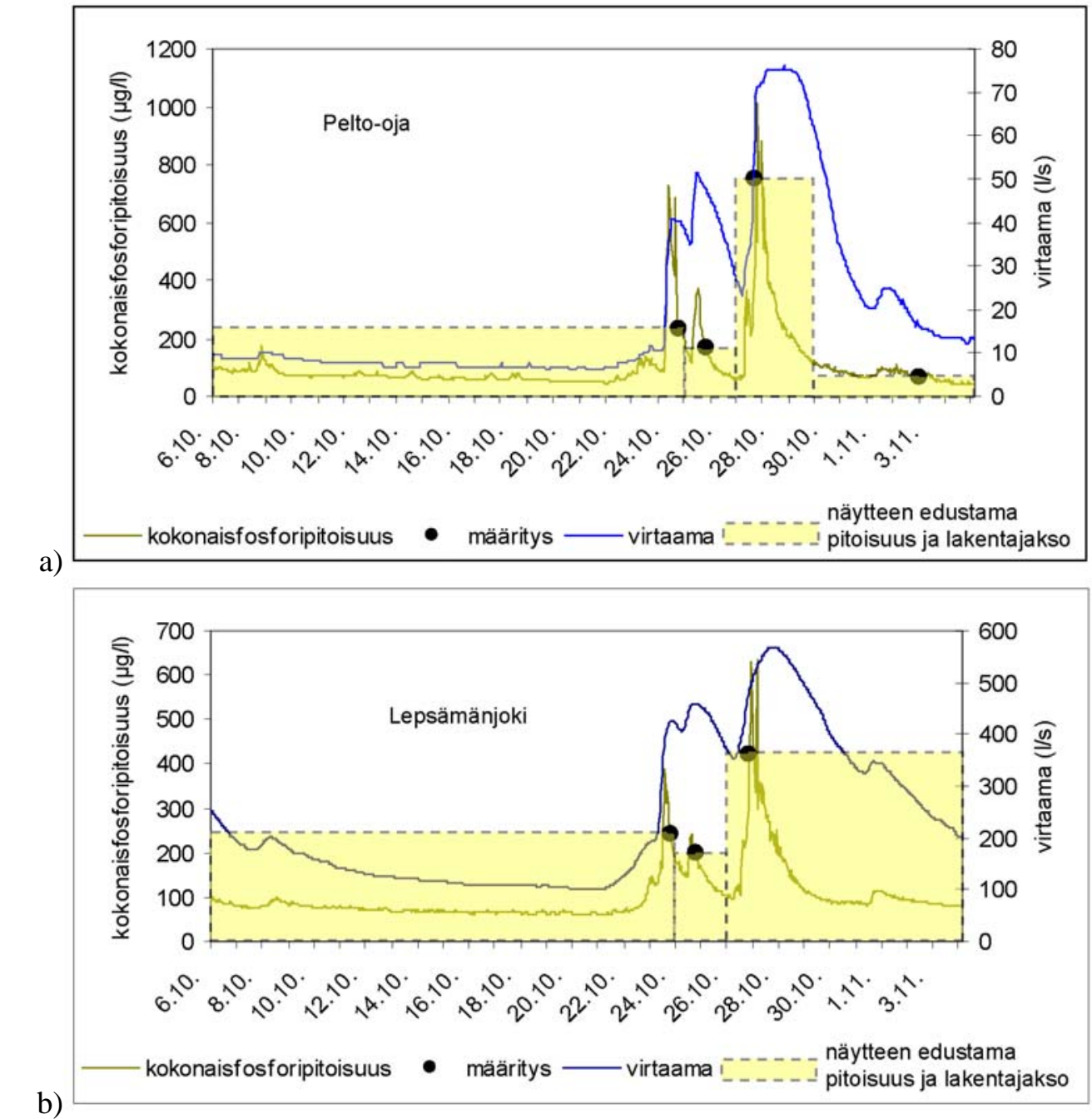

Kuva 2. Kokonaisfosforipitoisuuden vaihtelu ja virtaama tunnin välein sekä laboratoriossa tehdyt kokonaisfosforimääritykset ja yksittäisten näytteiden edustamat laskentajaksot syksyllä 2006 pelto-ojassa (a) sekä Lepsämänjoessa (b).

Syksyn 2006 tutkimusjaksolla ero laskentamenetelmien välillä pelto-ojan kohdalla oli 2,1-kertainen. Tämä jakso on esimerkki harvemman näytteenoton vaikutuksesta kuormituslaskentaan (kuva 2a) Toisaalta neljä näytettä kuukauden aikana ylivirtaamatilanteita painottaen ei välttämättä poikkea monien 
seurantaohjelmien vaatimuksista. Syksyllä 2006 kokonaisfosforipitoisuus nousi virtaaman nousuvaiheessa muutamassa tunnissa huippuunsa ja toisaalta laski lähes yhtä nopeasti virtaamasta riippumatta. Kokonaisfosforipitoisuudesta ei voidakaan virtaaman perusteella päätellä mitään. Vaikka kaksi ensimmäistä näytettä on otettu ensimmäisen virtaamahuipun aikana, ne on otettu liian myöhään todellisen huippupitoisuuden selvittämiseksi. Lepsämänjoesta otetut kolme näytettä ajoittuivat virtaaman nousuvaiheisiin (kuva 2b) ja siten niistä mitattiin melko korkeita kokonaisfosforipitoisuuksia. Laskentamenetelmien välinen ero nouseekin joen kohdalla noin 2,6-kertaiseksi anturitulosten perusteella lasketun tuloksen ollessa pienempi.

Kevään 2007 tutkimusjaksolla vesinäytteisiin perustuva fosforikuorma oli pelto-ojassa 1,2kertainen anturitulosten perusteella laskettuun kuormaan verrattuna. Tällöin suurin osa kuormituksesta tuli tutkimusjakson alussa virtaamahuipun molemmin puolin lyhytaikaisina piikkeinä (kuva 3a), mutta näytteenottoajankohdat edustivat jakson kuormitusta kohtalaisen hyvin. Lepsämänjoesta otettujen seitsemän vesinäytteen perusteella laskettuna saatiin 10 prosenttia pienempi kokonaisfosforikuorma kuin anturitulosten perusteella. Pitoisuusvaihtelu oli joessa hyvin voimakasta ja kokonaisfosforipiikit olivat korkeita. Näytteenottohetket eivät ajoittuneet korkeimpiin pitoisuuksiin (kuva 3b).

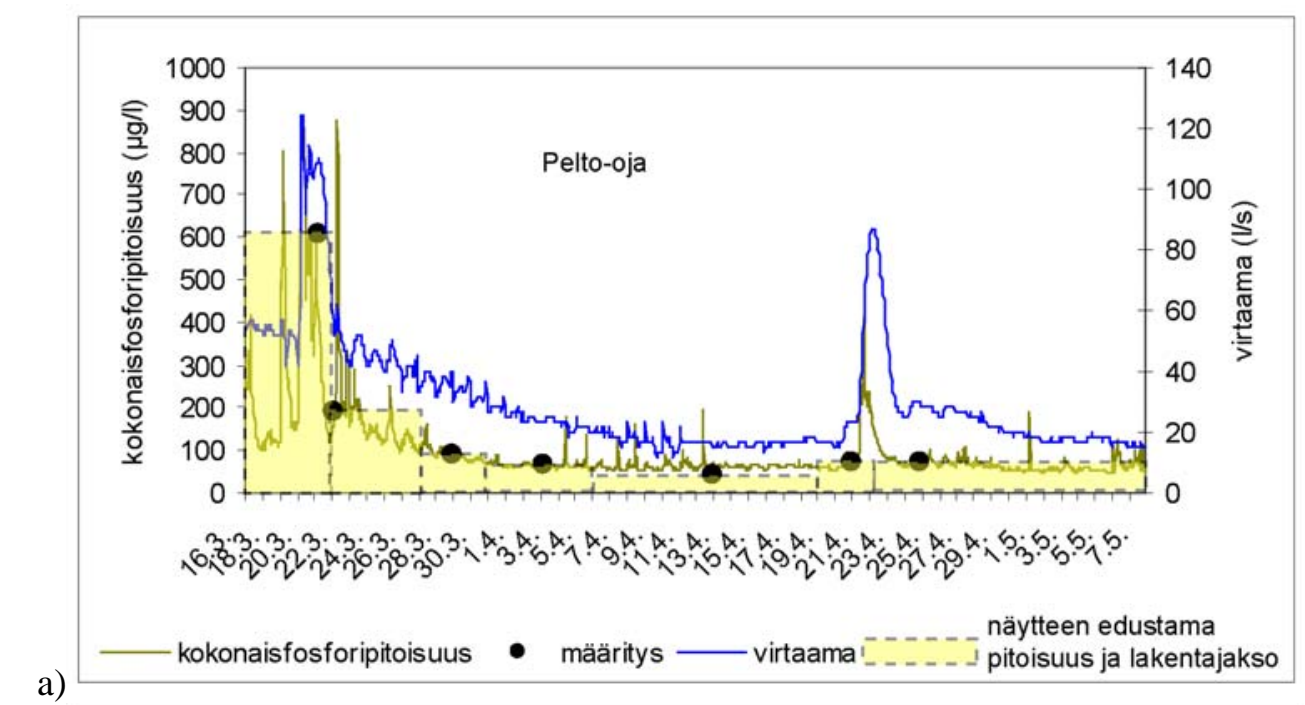

a)

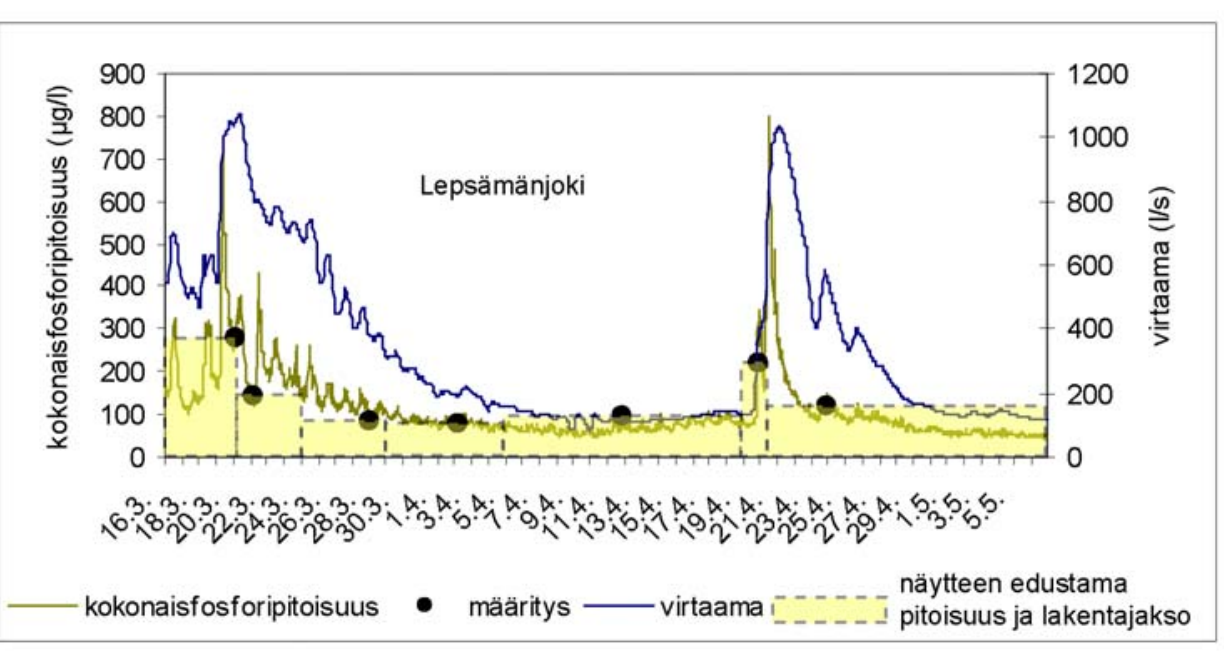

Kuva 3. Kokonaisfosforipitoisuuden vaihtelu ja virtaama tunnin välein sekä laboratoriossa tehdyt kokonaisfosforimääritykset ja yksittäisten näytteiden edustamat laskentajaksot keväällä 2007 pelto-ojassa (a) sekä Lepsämänjoessa (b).

Suurin osa vesistöihin huuhtoutuvasta ravinne- ja kiintoainekuormasta tulee kevään ja syksyn ylivirtaamakausina (Rekolainen 1992). Täten Lepsämänjoen ja pelto-ojan tulosten perusteella voitiin arvioida melko tarkasti vuoden 2006 aikana valuma-alueilta huuhtoutuneen kokonaisfosforin määrää pinta-alayksikköä kohden. Anturitulosten avulla laskettu fosforihuuhtouma oli pelto-ojan peltopinta-alaa 
kohden $64 \mathrm{~kg} / \mathrm{km}^{2} / \mathrm{v}$ ja yksittäisiin vesinäytteisiin perustuen $129 \mathrm{~kg} / \mathrm{km}^{2} / \mathrm{v}$. Lepsämänjoen valumaalueen peltopinta-alaa kohden fosforihuuhtouma oli vastaavasti $31 \mathrm{ja} 40 \mathrm{~kg} / \mathrm{km}^{2} / \mathrm{v}$. Vuorenmaa ym. (2002) ovat arvioineet pieniltä peltovaltaisilta valuma-alueilta huuhtoutuvan noin $110 \mathrm{~kg} / \mathrm{km} / \mathrm{v}$ fosforia peltopinta-alaa kohden. Näistä luvuista on vähennetty luonnonhuuhtouman osuus joka on 6,6-8,6 $\mathrm{kg} / \mathrm{km}^{2} / \mathrm{v}$. Keskimääräinen fosforihuuhtouma koko Lepsämänjoen valuma-alueelle $\left(214 \mathrm{~km}^{2}\right)$ on Ympäristöhallinnan VEPS-mallin mukaan $55 \mathrm{~kg} / \mathrm{km}^{2} / \mathrm{v}$ luonnonhuuhtouman osuuden ollessa 10 prosenttia. Peltopinta-alaa kohden VEPS-malli antaa fosforihuuhtoumaksi $163 \mathrm{~kg} / \mathrm{km}^{2} / \mathrm{v}$ (Ympäristöhallinto 2004).

\section{Johtopäätökset}

Vaikka tässä tutkimuksessa havaittiin jatkuvatoimisella veden laadun seurannalla saatujen kokonaisfosforikuormien olevan pelto-ojassa usein pienempiä kuin yksittäisiin vesinäytteisiin perustuvat laskennat, on näytteenottohetkellä lopputuloksen kannalta suurin merkitys. Lepsämänjoen tulosten perusteella nähdään, että myös päinvastainen tulos on mahdollinen. Myös laskentajaksojen jakaminen eri perustein saattaa muuttaa lopputulosta. Nykyinen virtaamapainotteinen veden laadun seuranta saattaa yliarvioida jonkin verran kuormitusta. Jos näytteenotto ajoittuu huippupitoisuuksien aikaan ja näytteenotto on harvaa, voivat yksittäisten näytteiden perusteella lasketut fosforikuormat olla hyvin virheellisiä. Tästä syystä näytteenotto myös pienten pitoisuuksien aikaan on tärkeä. Tällöin yksittäiset suuret pitoisuudet eivät vaikuta niin paljon kokonaistulokseen. Etenkin pienissä virtavesissä muutokset niin virtaamissa kuin veden laadussakin ovat niin nopeita, että yksittäisten vesinäytteiden perusteella tehtävät kuormituslaskelmat saattavat antaa hyvin virheellisen lopputuloksen.

Näytteenottoa suositellaan yleensä keskitettäväksi tulvajaksoille. Juuri tällöin kulkeutuu suurin osa kiintoaine- ja fosforikuormasta. Tulvan aikana tapahtuvat myös nopeat ja suurimmat muutokset kiintoaine- ja kokonaisfosforipitoisuudessa. Jos tulvan aikaisesta uomassa kulkeutuvasta kuormasta halutaan oikea kuva, tulisi näytteitä ottaa useita päivässä ja riippuen tulvan kestosta myös useamman päivän ajan.

Maatalouden ympäristötukitoimien vaikuttavuuden seurannan perusteella ei ole juurikaan havaittu muutoksia vesistöjä rehevöittävän kuormituksen pienenemisestä (Uusitalo ym 2007). Yksittäisiin vesinäytteisiin perustuvat kuormituslaskelmat antavat oikeansuuntaista tietoa, mutta niiden avulla ei saada tarkkaa tietoa kuormituksen todellisesta määrästä tai ajoittumisesta. Esimerkiksi kiintoaine- ja kokonaisfosforipitoisuudessa tapahtuvat muutokset ovat niin nopeita, että näytteenottohetken siirtäminen muutamalla tunnilla eteenpäin voi muuttaa tulosta kymmenkertaisesti. Jos halutaan seurata ympäristötukitoimien vaikuttavuutta vesistöihin, saattaa yksittäisten näytteenottoajankohtien perusteella tehtävät päätelmät oikaista laskelmia liikaa. Esimerkiksi fosforilannoitteiden vähentämisen seurauksena tapahtuva fosforin huuhtoutuminen vesistöihin vähenee hitaasti. Fosforin huuhtoutumisen seurantaan automaattiset veden laatua mittaavat anturit ovatkin erinomainen menetelmä ainakin savialueilla. Jatkuvatoiminen veden laadun seuranta on myös hyvä keino havaita mahdollisia hienovaraisia muutoksia vesien tilassa mukaan lukien ympäristötukitoimien mahdolliset vaikutukset.

Tulosten perusteella voidaan todeta peltovaltaisilta valuma-alueilta tulevan kuormituksen vaihtelevan hyvin voimakkaasti eri vuosien välillä. Keväällä lumen sulamisen seurauksena muodostuu merkittävin osa tällaisilta valuma-alueilta tulevasta kuormituksesta. Syksyllä ylivirtaamakauden osuessa aikaan, jolloin suurin osa pelloista on vielä kyntämättä ja kasvillisuus suhteellisen rehevää, ei edes ennätyssuuri sademäärä nosta kuormitusta kevään tasolle. Keväällä olosuhteiden voidaan sanoa olevan lähempänä esimerkiksi leutojen talvien aikana vallitsevia olosuhteita. Tällöin kasvillisuus on vähäistä ja osa pelloista syyskynnön jäljiltä paljaana ja alttiina eroosiolle. Ilmaston lämpenemisen myötä leudontuvat talvet lisäisivät siis tämän tutkimuksen perusteella hajakuormitusta. Merkitystä on kuitenkin myös sademäärillä, sateiden ajoittumisella ja roudalla.

Vuosittainen vaihtelu hajakuormituksen määrässä johtaa myös maataloudesta tulevan kuormituksen osuuden vaihteluun kokonaiskuormituksesta. Pistekuormituslähteinä toimivien yhdyskuntien puhdistamoiden vesistöön kohdistamat ravinnekuormat ovat helpommin laskettavissa ja vaihtelu niissä on vähäisempää kuin hajakuormituksessa. Jatkuvatoimisella seurannalla on nyt myös hajakuormituksen määrästä mahdollista saada totuudenmukaista tietoa ja sen rehevöittävän kuorman arvioiminen on luotettavuudeltaan samalla tasolla pistemäisistä lähteistä tulevan kuormituksen kanssa. 


\section{Kirjallisuus}

Aura, E., Räty, M. \& Hartikainen, H. 2006. Savimaiden eroosio: prosessit ja torjunta. Teoksessa Alakukku, L. (toim.): Maaperän prosessit - pellon kunnon ja ympäristönhoidon perusta. Maa- ja elintarviketalous 82, 37-43. Hynes, H. B. N. 1970. The ecology of running waters. 555 s. Liverpool University Press, Suffolk.

Kauppi, L. 1982. Testing the applicability of the CREAMS model to estimation of agricultural nutrient losses in Finland. Publications of the Water and Environment Research Institute 49, 30-39.

Lehtinen, K., Koponen, J. \& Frisk, T. 1993. Keski-Päijänteen virtaus- ja vedenlaatumallisovellus: fosforikuormittajien vesistövaikutusten arviointi. Vesi- ja ympäristöhallituksen monistesarja $464.52 \mathrm{~s}$.

Leinonen, A. 1992. Vedenlaatu ja ravinteiden hajakuormitus Tourujoen vesistöalueella 1989-1991. Vesi- ja ympäristöhallituksen monistesarja 379. $146 \mathrm{~s}$.

Niemi, J. S. 1998. The quality of river waters in Finland. European Water Management 1: 3, 36-40.

Niemi, J. S. 2006. Ympäristön tilan seuranta Suomessa 2006-2008. Suomen ympäristö 24/2006. 151 s.

Nykänen, I. 1991. Tainionvirran hajakuormitustarkastelu. Mikkelin vesi- ja ympäristöpiiri 4. 16 s.

Rekolainen, S. 1992. Maatalouden aiheuttama typpi- ja fosforikuorma vesistöihin. Teoksessa Rekolainen, S. \& Kauppi, L. (toim.): Vesi- ja ympäristöhallituksen monistesarja 359 - Maatalous ja vesien kuormitus. Yhteistutkimusprojektin tutkimusraportit, 9-15.

Räike, A., Granlund, K. \& Ekholm, P. 2004. Nutrient load from agricultural land and its effects in surface waters - evaluation based on monitoring data. Teoksessa Turtola, E. \& Lemola, R. (toim.): Maatalouden ympäristötuen seuranta MYTVAS 2. Osahankkeiden 2-7 väliraportit 2000-2003. Maa- ja elintarviketalous 59, 98-109.

Scherer, U. 2000. Modelling phosphorus transport processes in small southern German rural catchment. The role of erosion and sediment transport in nutrient and contaminant transfer. IAHS Publication 263, $285-292$.

Särkelä, A., Lahti, K., Vahtera, H., Penttilä, S. \& Ahtela, I. 2006. Automaattinen veden laadun seuranta avuksi hajakuormituksen arviointiin. Vesitalous 4/2006, 20-25.

Tikkanen, M., Seppälä, M. \& Heikkinen, O. 1985. Environmental properties and material transport of two rivulets in Lammi, southern Finland. Fennia 163: 2, 217-282.

Uusitalo, R., Ekholm, P., Turtola, E., Pitkänen, H., Lehtonen, H., Granlund, K., Bäck, S., Puustinen, M., Räike, A., Lehtoranta, J., Rekolainen, S., Walls., M \& Kauppila, P. 2007. Maatalous Itämeren rehevöittäjänä. Maa- ja elintarviketalous 96, 34 s.

Valkama, P., Lahti, K. \& Särkelä, A. 2007a. Fosforikuormituksen arviointi pelto-ojan valuma-alueelta ylivirtaama-aikoina. Vesitalous 5/2007, 30-34.

Valkama, P., Lahti, K. \& Särkelä, A. 2007b. Automaattinen veden laadun seuranta Lepsämänjoella. Terra 119: 3-4, 195-206.

Vuorenmaa, J., Rekolainen, S., Lepistö, A., Kenttämies, K. \& Kauppila, P. 2002. Losses of nitrogen and phosphorus from agricultural and forest areas in Finland during the 1980s and 1990s. Environmental Monitoring and Assessment 76: 2, 213-248.

Ympäristöhallinto 2004. Vesistökuormituksen arvioinnin VEPS 2.0-järjestelmä. Mallinnusohjelma. 